\title{
GIS Based Route Network Analysis for Tourist Places: A Case Study of Greater Imphal
}

\author{
T. Prameshwori" ${ }^{*}$, Wangshimenla. Ja, L. Surjit ${ }^{b}$, L. Ramananda ${ }^{b}$ \\ aDepartment of Geography, Nagaland University, Lumami, Nagaland, India \\ bDepartment of Science and Technology, Manipur Remote Sensing Applications Centre, Imphal, Manipur, \\ India
}

Article Info

Volume 8 Issue 2

Page Number: 233-238

Publication Issue :

March-April-2021

\section{Article History}

Accepted : 20 March 2021

Published : 29 March 2021

\section{ABSTRACT}

Greater Imphal area, located in the central part of Manipur that classified as a valley area. Greater Imphal area has a potential as a new tourism attraction within its Greater Imphal. ArcGIS network analysis provides to build the most efficient travel route, generating travel directions, locating the closest facility and defining service area based on travel time and distance covered which will help an opportunity in development of tourism. Using GIS technology it is possible to visit different tourist sites effectively with a deliberate decision. The present study aim to explore the GIS based network analysis in defining the optimal route and services such as hospital, shopping centre, market areas and universities that located in Greater Imphal area for tourist destination. Route analysis capabilities of GIS are done on the basis of estimate travelling time and distance in terms of time through a network. It is shown that using GIS in routing help a powerful ability for network analysis, management of shortest and closest facility analysis which benefits users to provide optimum planning for tourism.

Keywords: Greater Imphal, Tourism, Travel Route, Closest Facility and optimal Route.

\section{INTRODUCTION}

Tourism is a fast-growing and one of the world's largest industries. According to the United Nations World Tourism Organization (UNWTO), "tourism comprises the activities of persons travelling to and staying in places outside their usual environment for not more than one consecutive year for leisure, business and other purposes not related to the exercise of an activity remunerated from within the place visited". [5]

GIS technology offers great opportunities for the development of modern tourism applications using maps. Tourists who want to visit the sightseeing destination need to have information and visual 
representation about those places with the help of GIS tool. [3]

The shortest path problem is the problem of finding the shortest path or route from a starting point to a final destination. We use graphs to represents the shortest path problems. it is a mathematical abstract object. It contains sets of vertices and edges. [1]

Tao Peng and Xiaowen Wang, works on the project where they used the mobile based navigation web application system. The authors basically works on hinder factors like hospitals, schools, residential areas, traffic lights and the user-controlled factor of traffic and driving speeds for proving route plan, which finds the shortest path and shows he result as online map via web GIS application. The main aim of the project was to use the web GIS and GNSS technology with open source data and tools, to combine web GIS and mobile phones with GPS module for designing and developing a web base application which provides intelligent vehicle navigation system. Authors used Dijkstra's algorithm to find the shortest path. [8]

GIS enables network analysis to determine the shortest and best route which helps the tourist to plan and various tourist places from their accommodation will benefit tourist time and economy. Using GIS in routing help a powerful ability for network analysis, management of shortest and closest facility analysis which benefits users to provide optimum planning for tourism.

\section{METHODS AND MATERIAL}

\section{STUDY AREA}

Greater Imphal is fall in the category of Manipur valley region lies between $24^{\circ} 52^{\prime} 39.8^{\prime \prime} \mathrm{N}$ and 24053'21.3"N latitude and between 93052'39.8" $\mathrm{E}$ and 93059'16.7"E with an area of 1.333sq.km and has an altitude of 780 MSL. Greater Imphal has identified around 16 tourist spots which include various historical, cultural and gifts of nature. Greater Imphal comprises some portion of Imphal-East and ImphalWest district and fast growing city with good road network which connected to all tourist destinations.

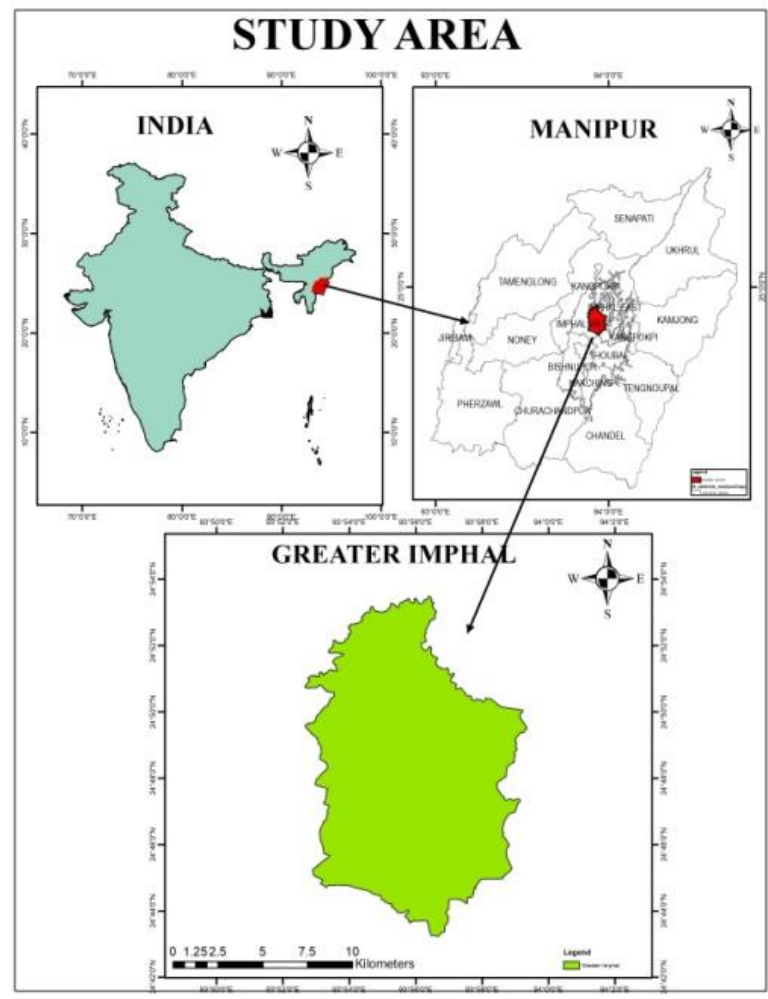

Figure 1 : The Study Area

\section{DATA USED}

Indian Remote Sensing satellite (IRS) LISS-IV (5.6m) satellite data was used to prepare the road and places of a tourist destination. The study area based map, road network data, Hospitals, Universities, police stations, hotels, tourist sites, and then Geo-referencing the based map.

\begin{tabular}{|c|c|c|}
\hline $\begin{array}{c}\text { ROAD } \\
\text { CLASSIFICATI } \\
\text { ON }\end{array}$ & WIDTH (MT.) & $\begin{array}{c}\text { SPEED } \\
\text { (KMH) }\end{array}$ \\
\hline AH & 40 & 40 \\
\hline $\begin{array}{c}\text { DISTRICT } \\
\text { ROAD }\end{array}$ & 25 & 30 \\
\hline MINOR ROAD & 10 & 20 \\
\hline
\end{tabular}

Table I : Width and Speed of the Road 


\section{CREATION OF GEO-DATA BASE}

To create Geo-Database following data has been used:

- Greater Imphal base map using LISS-IV.

- Greater Imphal road network shapefile.

- Shapefile of tourist places, hotels, airport, bus terminal as well as public services like Hospitals, Universities, Market places.

\section{DATA PROCESSING AND ANALYSIS}

In this paper, the schematic representation of the work-flow with seven stages begins with collecting primary and secondary data as shown in figure 2 , then spatial data processing and Geo-referencing the base map of the study area. The network topology and the network dataset were built. Finally, the road analysis has been used in the network analysis of the Greater Imphal region.

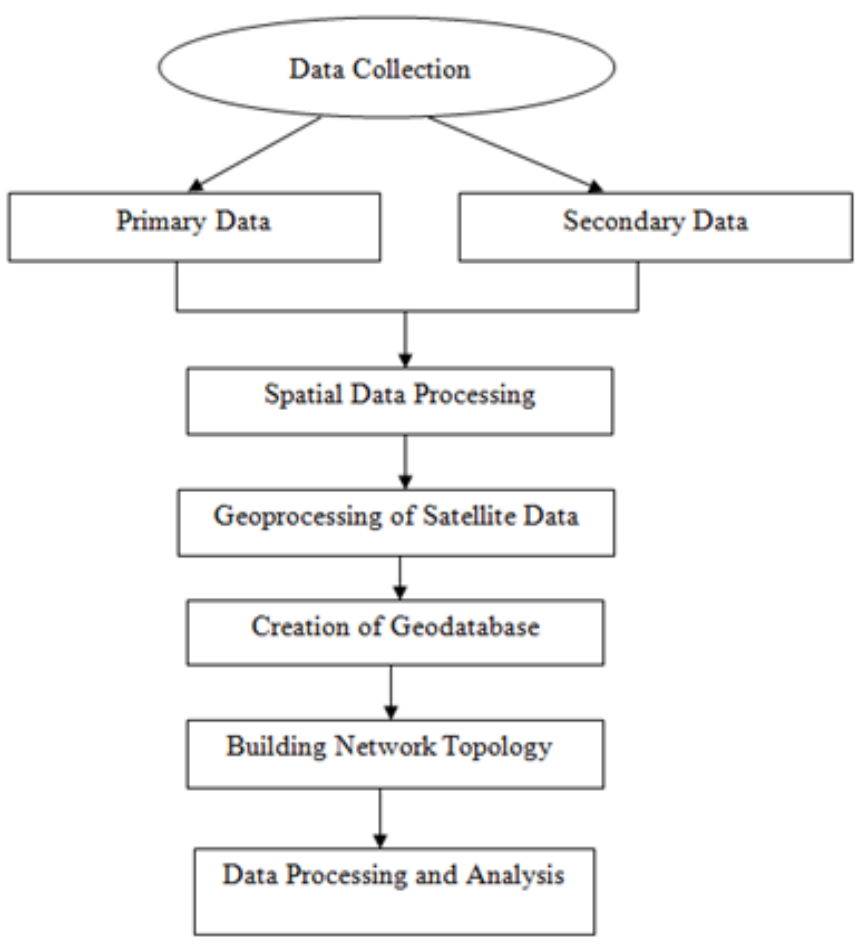

\section{RESULT AND DISCUSSION}

Finding the shortest path and best route between places which is less time and less cost consuming in travelling

The best route between two locations which based on less time and cost consuming in travelling. The best route analysis finds the route to start location and the end location. Figure 3. Shows the best route between start location (location 1) and end location (location 2) which will determine the order of location specified by the user. It is the best route to get from one location to different tourist sites or the best way to visit several locations.

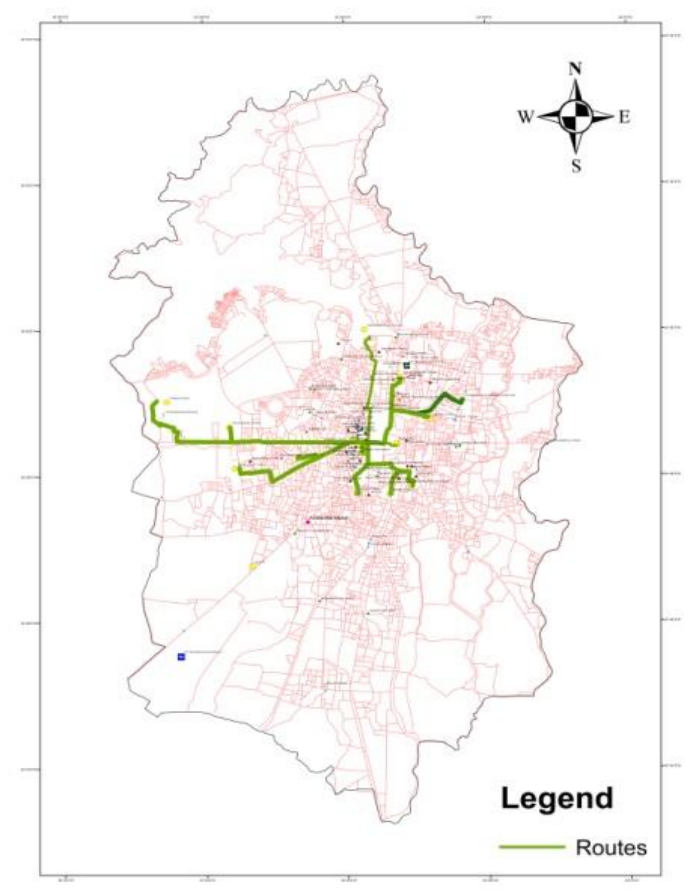

Figure 3 : The Best Route Map

Figure 2 : Workflow 


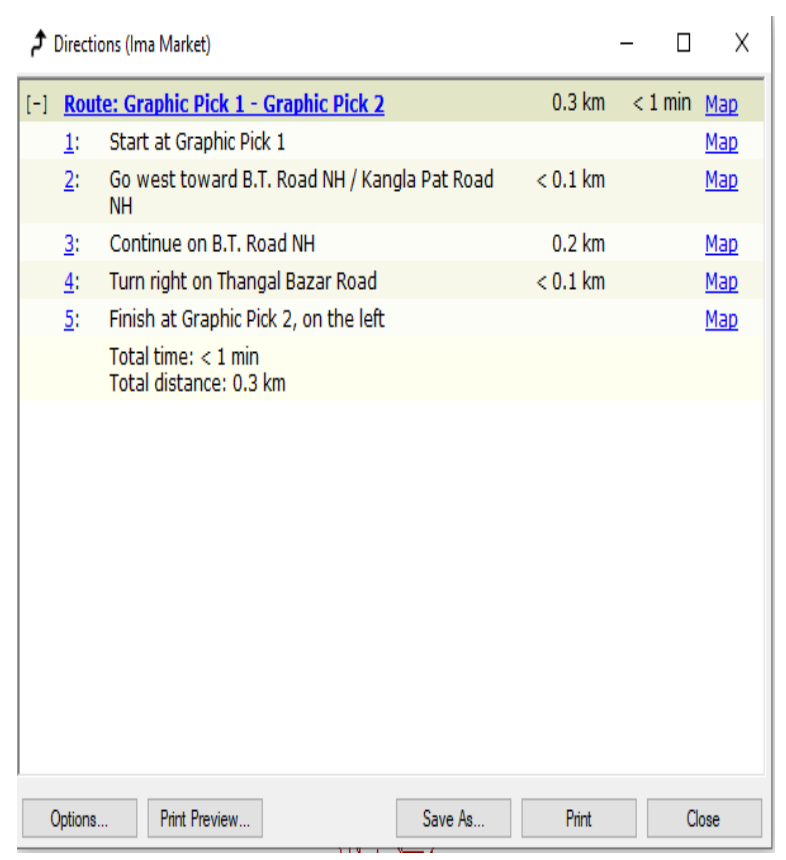

Figure 4 : Direction window of the best route

\section{Closest Facility analysis}

The closest facilities analysis finds the closest facilities that can be reached in a specific period from tourist sites based on travel time and traffic information available which determine the user to locate the specified location. The map represented seven closest tourist places to the heart of the city as shown in figure 5 .

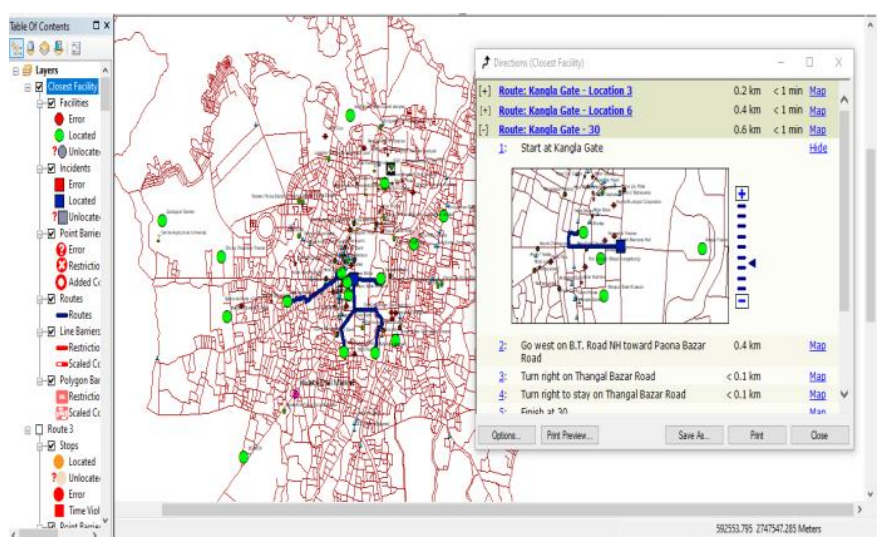

Figure 5 : Closest Tourist sites from Heart of City

Based on distance and time for service area with different facilities
Figure 6. Shows that the spatial distribution of different services such as hospitals, universities, hotels, tourist places, airport, bus terminal, police stations through a route network which is also known as service allocation analysis. With the help of this analysis, the efficiency of these services in terms of time and distance may be analyses the actual service area of different facilities or whether these facilities are enough for that area, if not then how much it required.

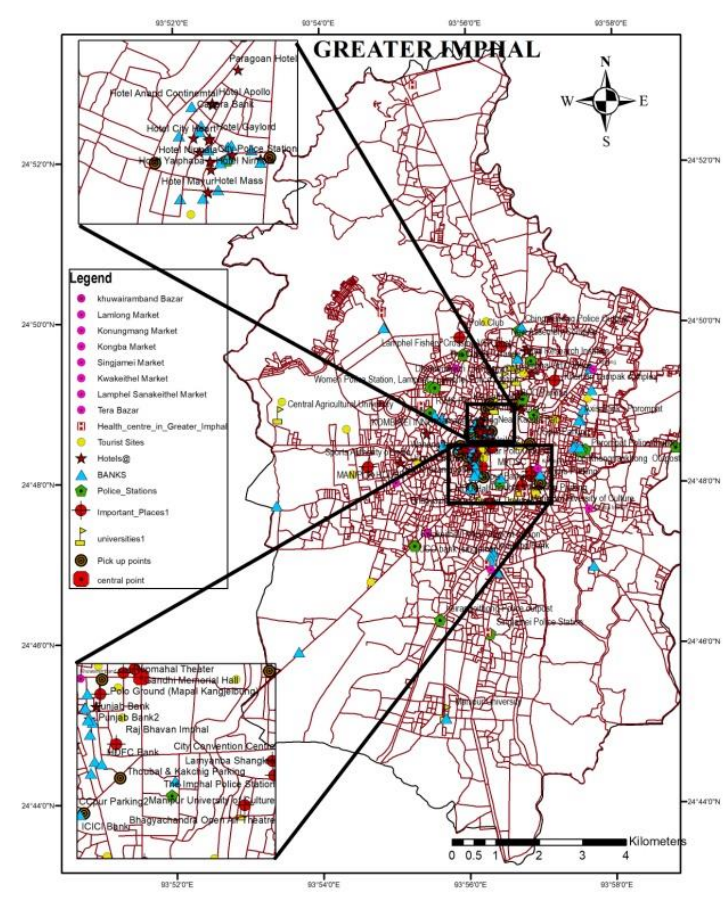

Figure 6 : Greater Imphal Service Area Service area for different market Places 


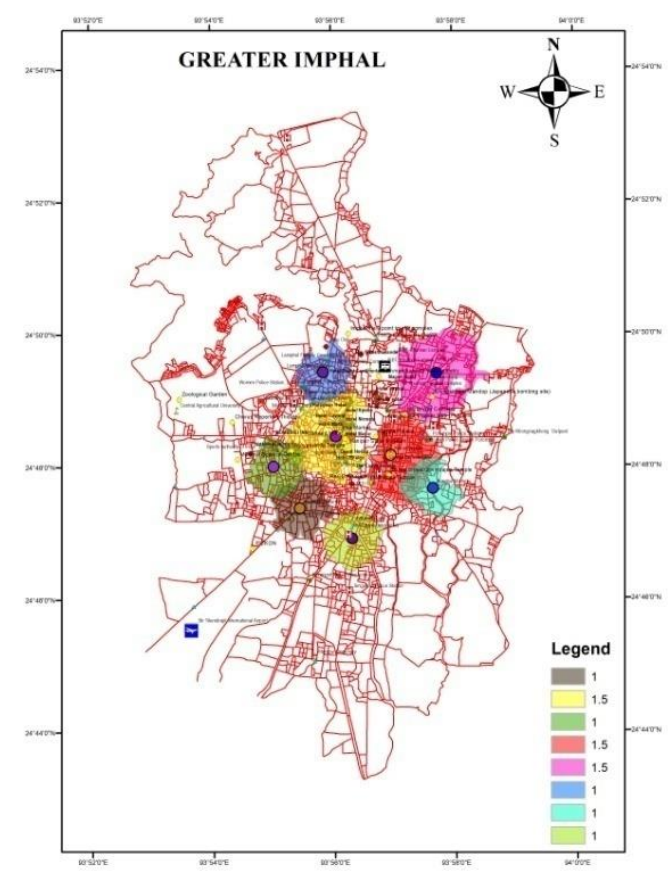

Figure 7 : Service area for different market places

From above map (figure 7) shows the service area based the on buffer with an estimated travelling distance of 1 and $1.5 \mathrm{~km}$ cover each market centres which shown the availabilities of shopping malls, restaurants and other amenities for tourist people are available.

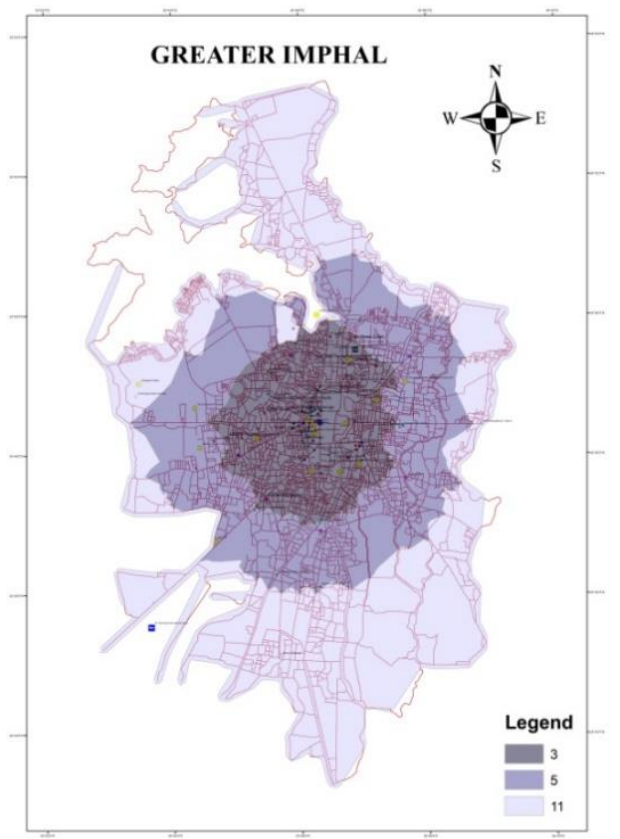

Figure 8 : Proposed Service area for Tourism
The above map (figure 8) shows three service area polygons which calculated for each facility in a service area for amenities based on travel distance, with a buffer of 3, 5, $11 \mathrm{~km}$. The dark colour means a sufficient amount of amenities are available in this area. The area has less availability of amenities for tourism and new more amenities are required.

The present study found that due to different road speed travelled, if the length is taken as impedance it covers $52.8 \mathrm{~km}$ distance but if the time is taken as impedance it cover $53 \mathrm{~km}$ distance. The only 1 minute difference of time speed between both impedance routes as only higher-order taken into consideration for the study. Along with the best route ArcGIS network analysis provides a turn by turn route map and visual representation of the tourist sites in figure 3.

\section{CONCLUSION}

The GIS network analysis application help to find the best route between two locations on the road network and helpful for optimum planning for sightseeing with time and length impedance. The study enhanced GISbased network analysis focuses on finding the best route, closest facility analysis, and service area determined analysis help the users to plan for tourism. Therefore, in the future GIS-based network analysis which helps user to save time and satisfaction.

\section{REFERENCES}

[1]. Amrapali Dabhade, Dr. K. V. Kale, Yogesh Gedam. 2015, "Network Analysis for Finding Shortest Path in Hospital Information System." International Journal of Advanced Research in Computer Science and Software Engineering, Vol. 5, ISSN: 2277 128X.

[2]. Mohamed ElAmin Ahmed Babiker, Suaad M. Abuelwafaa, 2017, "GIS Based Urban Road 
Network Analysis in Khartoum Center" Cite this article as :

IJSRSET, Vol. 3, ISSN: 2395-1990.

[3]. N. GillI and B.D. BharathII. 2013, T. Prameshwori, Wangshimenla. J, L. Surjit, L. "Identification Of Optimum Path For Tourist Ramananda, "GIS Based Route Network Analysis for Places Using Gis Based Network Analysis: A Tourist Places : A Case Study Of Greater Imphal", Case Study Of New Delhi." International International Journal of Scientific Research in Science, Journal Of Advancement In Remote Sensing, Engineering and Technology (IJSRSET), Online ISSN : GIS and Geography, Vol.1, No.2, 34-38. ISSN 2394-4099, Print ISSN : 2395-1990, Volume 8 Issue 2, 2321-8355.

pp. 233-238, March-April 2021. Available at

[4]. Parveen Kumar and Dinesh Kumar. 2013, doi : https://doi.org/10.32628/IJSRSET218229

"Network Analysis using GIS Techniques: A Journal URL : https://ijsrset.com/IJSRSET218229

Case of Chandigarh City." International Journal

of Service and Research (IJSR), ISSN (Online): 2319-7064.

[5]. Recommendations on Tourism Statistics, United Nations Department for Economic and Social Information and Policy Analysis Statistical Division and World Tourism Organization, Series M No. 83, United Nations New York, 1994.

[6]. Tamrat kasahun, Jayesh Juremalani and Siddharth Gupte. 2018, "Developing Thematic GIS Database Integrating Road Network Management System: A Review.” International Research Journal of Engineering and Technology (IRJET), Vol. 5, ISSN: 2395-0056.

[7]. Shu Tang and Hao Tang. 2015, "The Network Analysis in Rural Tourism Land UseBased on GIS.” Trans Tech Publications, Switzerland, Vol 1092-1093 (2015) pp 1313-1316

[8]. Tao Peng and Xiaowen Wang, "A Mobile-based Navigation Web Application: Finding the Shortest-time Path based on Factor Analysis", June 2012. 